\title{
REPUTATION AND WORD-OF-MOUTH PERCEPTION: CASE STUDIES IN INSTITUTIONAL MANAGEMENT
}

\author{
Christina Menuk Sri Handayani1, Fauziyah2 Tri Ariprabowoz \\ 1,3 Department of Management, Faculty of Economy, PGRI Adi Buana University Surabaya \\ 2 Department of Accounting, Faculty of Economy, PGRI Adi Buana University Surabaya \\ E-mail: menukch@unipasby.ac.id
}

\begin{abstract}
The purpose of this research is to analyze the perception differences of reputation and word of mouth between educational and non-educational program students in choosing UNIPA Surabaya as their place of study. Using quantitative approach with the survey method, we sample 172 educational program students and 164 noneducational program students. The data is processed using multiple regression by first going through validity, instrument reliability and classical assumption tests. Analysis showed that there are significant differences between educational and noneducational program students in choosing UNIPA Surabaya as their place of study seen from the word of mouth perception, but no significant differences seen from the reputation perspective.
\end{abstract}

Keywords: $\quad$ reputation, word of mouth, study decisions

\section{Introduction}

Today's industrial era affects much of the business world's development and growth, both for production sector or service sector such as education. A company requires education as part of its human resource development. Education helps in shaping thought and develop better wellbeing. Higher education in society indirectly results in better-equipped young to help push for better economic development. The society as a whole has realized that better knowledge, education and skills are needed to face problems that continue to occur as the information age grows. To assist this, a certain institution is needed to accommodate and fulfill the society's need for higher learning, such as universities.

Universities in Indonesia incurs significant growth in recent years. The Ministry for Research, Technology and Higher Learning in late 2019 recorded 4.488 higher learning institutions. This is more than the sum total of universities in Europe. More than 50\% are private institutions, and are able to hold more than 7 million students and 250 thousand professors (Fauzan, 2016).

Competition for new students will cuntinue to increase due to the saturation of universities. TO face the competition, efforts are done by universities to sho their potency and excellence, using branding and direct communication with prospective students (Medan, 2018). Good reputation and branding for a given university will help in inter-institution competition, especially foreign universities (Aula \& Tienari, 2011). Reputation is also considered asn the main competence for an education institution to compete in the global market (Mazzarol, Soutar, \& Limnios, 2012).

Researchers may define reputation as an intangible asset due to its continual contribution in achievements of excellence in an organization, and as a marker of future prospects and past achievements for future stakeholders to look for. This condition pushes universities to reach competing excellence by attracting great students, itself attracting great companies. A university's goal, aside from satisfying its students, is to increase its marketing value. A given university's marketing value rises if the students are given adequate satisfaction, such as good professors, comfortable lecture rooms, adequate infrstructure, competitive curriculum, and effective teaching strategies. Marketing value also serves to protect the institution's interests, such as welfare for the professors and employees, university reputation and development (Sonjaya, 2014). 
International Journal of Economics, Business and Accounting Research (IJEBAR)

Peer Reviewed - International Journal

Vol-4, Issue-2, 2020 (IJEBAR)

E-ISSN: 2614-1280 P-ISSN 2622-4771

https://jurnal.stie-aas.ac.id/index.php/IJEBAR

Institutions require the correct strategies to be able to survive and win the competition to earn their achievements. This strategy must also be implemented systematically and in the long term. University promotions are a priority component due to it being the main way for the institution to inform, persuade and remind the society about the product. (P. Kotler, 2012) stated that promotion is a set of means used by a company to inform, persuade and remind the comsumer bot directly or indirectly about the product being sold. Promoting requires communication to help the consumer decide before buying. Usually, the consumer will first research about their desired products, usually from family, friends, or close associates. This type of communication is called word of mouth communication.

Word of mouth is a private communication process between the customer and their surroundings about the product (P. Kotler, 2012), while (Eka, 2015) stated that word of mouth is an informal information exchange between a noncommercial messenger to the receiver about a particular product, service, brand or company that the messenger has experienced.

This information model is very effective in affecting the final purchase decision, as stated by (Hasan, 2010), where word of mouth information were one of the strongest source for a customer to finalize their purchase decision. (P.\&K.L.K. Kotler, 2009) defined marketing as the science or art of building active and profitable communication between customers or between the customer and the seller. (Sernovitz, 2009), defined word of mouth marketing as an action taken by the company to expand word of mouth information capabilities using good ads, correct promotions, and publications in media and event such as that the customers will keep talking about the product or service.

This condition is also felt by UNIPA Surabaya, one of the Top 100 best universities in Indonesia, such that it always tries to innovate to compete with other universities. As a university known for its output of teachers, itself starting as an institute by teachers, UNIPA Surabaya always promotes itself as not just for educational students, but also for non-educational program students.

Through promotions, the university informs the populace that non-educational graduates can also be teachers (Islamic Education General Directorate, 2017, https://kemenag.go.id/berita/read/505736, asserted by (Pemerintah RI, 2005) Articles 1 and 2 states that Teachers are professional educators, proven by an educator's license.

These conditions allow the people to lots of choices on how to continue to a university of their choice, adjusting to their own conditions. These choises ultimately shape the final decisions of the students themselves.

\section{Literature Review \\ 2.1 University Reputation}

Conceptually, reputation is interpreted differently (Rindova et.al in (Wibowo, 2014)) Many researchers classify reputation as a process of evaluating the entensity of a company or organization. Reputation is defined as an assessment of the relationship of attitudes, emotions, financial, social and cultural of an organization. Likewise Post \& Griffin (Harahap, Hurriyati, Gaffar, Wibowo, \& Amanah, 2017) reputation is a combination of opinion, perception and behavior of the stakeholders of an organization.

In choosing a tertiary institution, the reputation of the tertiary institution and the suitability of the study program are separate considerations. The community knows the reputation of tertiary institutions from the BAN-PT accreditation status owned by such tertiary institutions, therefore the manager is trying to get the best value for the institution or study program (Gunarto \& Gaffar, 2016) Related to tertiary institutions, the corporate reputation of the tertiary institution defined as subjective and collective recognition, perceptions, attitudes and evaluations of institutions established among all internal and external stakeholder groups over a period of time. (Mehboob, Shah, \& Bhutto, 2012) found that the university's reputation was important for a graduate who would find a job to understand, 


\section{International Journal of Economics, Business and Accounting Research (IJEBAR) \\ Peer Reviewed - International Journal \\ Vol-4, Issue-2, 2020 (IJEBAR) \\ E-ISSN: 2614-1280 P-ISSN 2622-4771}

https://jurnal.stie-aas.ac.id/index.php/IJEBAR

because the university institution where he studied created his own image and carried his reputation among the industry. Universities are becoming more competitive in markets that try to attract the best students and then provide the best job opportunities for students who have been accepted.

Such conditions can lead universities to create competitive advantage in order to get the best prospective students. The college reputation of a graduate who works in a company will be known for his performance. Dismping the students feel that study at one particular university can show the level of success in getting a job and the perception of salary to be earned, company preferences in the job market, a sense of pride and worthiness of students in the job market (Sultan and Wong in (Wibowo, 2014)).

Choosing the right university for higher education is a crucial issue. There are several factors that play a role and are appropriate for higher studies, these factors are reputation, school fees, permanent location of campus, quality of teaching staff, online services and information technology facilities, advertising and environment (Saif, Nipa, \& Iddique, 2016) Factors The foregoing agrees with the results of the study (Hagel \& Shaw, 2007), (Agrey \& Lampadan, 2014), (Rudhumbu, Tirumalai, \& Kumari, 2017). The explanation above, it can be stated that reputation is the result of collective assessment by outsiders of an organization on the performance and quality of the organization that is long-term in nature. According to Larkin in (Suta, 2006) reputation is expressed as a perception of the characteristics, performance and behavior of the organization, it can be constructed the factors forming reputation as follows 1) CEO, 2) University governance, 3) Social responsibilities, 4) Accounting measures.

\subsection{Word of Mouth}

Word of mouth communication (WOM) or communication from mouth to mouth is a communication process in the form of giving recommendations individually or in groups of a product or service (Kotler \& Keller, 2016). Whereas (Sernovitz, 2009) word of mouth marketing is a communication process to give a reason for someone to talk about a product or service in order to facilitate the conversation. The American Communication Institute (AMA) defines word of mouth communication as the exchange of information between consumers about products and promotions (Association American Marketing, n.d.). WOM is considered as one of the most influential factors on consumer behavior (Huete-Alcocer, 2017).

Word of mouth is not engineered because consumers provide information voluntarily and do not get rewarded Prasetyo (2018). The information submitted can be good but can also be made up or not in accordance with reality so that it can be bad for the company, can damage the company's brand and reputation itself. If this happens in the determination of the choice to continue their studies to college, it is a decision that will have an impact on the future concerned. Prospective students will always look for information to the stage of stability to determine the choice of admission to the university which according to him is the best university among others. To minimize the risk that will be borne in the future, prospective students often share word of mouth.

The power of word of mouth face to face or online cannot be underestimated. WOM plays an important role in the decision making of a consumer in the process of selecting or determining an object (Harahap, Hurriyati, Gaffar, Wibowo, \& Amanah, 2017). Every college needs prospective students to need various effective marketing methods to attract prospective students. (Özdemir, Tozlu, Şen, \& Ateşoğlu, 2016) state that when choosing a university, word of mouth information is most influential. (Sernovitz, 2009) states word of mouth is communication that produces good conversation. Someone will ask others about the quality of an item or service before deciding to buy, so he divides the five dimensions or basic elements of word of mouth known as 5T, namely: Talkers, Topics, Tools, Talking part and Tracking 
International Journal of Economics, Business and Accounting Research (IJEBAR)

Peer Reviewed - International Journal

Vol-4, Issue-2, 2020 (IJEBAR)

E-ISSN: 2614-1280 P-ISSN 2622-4771

https://jurnal.stie-aas.ac.id/index.php/IJEBAR

\subsection{Decision to Choose Higher Education}

The process of a person's decision making starts from the need to be fulfilled. To be able to meet the needs associated with various alternatives so that evaluation is needed to obtain the best alternative according to the perception of someone as a consumer. So that the comparison process can run smoothly, information is needed according to the amount and level of importance, which is adapted to the needs of a person in the conditions and situations encountered (Sudaryono, 2014). The purchasing decision process as stated (Kotler \& Keller, 2016) includes 1) Recognition of Problems 2) Information Search 3) Alternative Evaluation 4) Purchasing Decisions 5) Post-purchase Behavior. While Schiffman and Kanuk in (Wulandini \& Saputra, 2017) the decision making process is an important process that is influenced by the external environment such as the marketing mix (4P) and the sociocultural environment such as family, information sources, non-commercial sources, social classes, culture and sub-culture, while the internal environment in the form of psychological factors such as motivation, personality, learning, perception, and attitude.

Deciding to choose a college as a place of study is a crucial problem. Many factors play a role in choosing the right university for higher studies (Saif, Nipa, \& Siddique, 2016), Ming in (Mahendra Fakhri, Alini Gilang, 2017) states that the decision of students to choose higher education is influenced by no factor 1) Student characteristics include interests or talents 2) External influences such as parents, friends and other individuals 3) Attributes of the college itself such as location, study programs, reputation, facilities, costs, job opportunities and marketing carried out. Students in making decisions on choosing tertiary institutions get advice from their closest people, the family. This is consistent with the phrase (Sumarwan, 2011) that the family is the closest environment to consumers. Family is an environment where most consumers live and interact with other family members.

\section{Research Methods}

To answer the problem with a causal research, the population for this research is drawn from UNIPA Surabaya students from the 2018-2019 academic year, differentiated between educational and noneducational program. The samples are counted using the Slovin algorithm (Arikunto, 2010) $n=$ $\frac{N}{1+N e^{2}}$, with accuracy rates of $95 \%$, with 164 taken from non-educational students and 172 taken from educational students. Data is taken using a questionnaire, to which instrument test and classical assumption test is applied, then analyzed using the multiple regression quantitative method. The research variable indicators are as follows.

Table 1. Variables and Indicators

\begin{tabular}{|c|c|c|}
\hline No & Variable & Indicator \\
\hline 1 & Reputation (X1) & $\begin{array}{l}\text { 1. CEO } \\
\text { 2. University governance, } \\
\text { 3. Social responsibilities } \\
\text { 4. Accounting measures (Larkin (Suta, } \\
\text { 2006)) }\end{array}$ \\
\hline 2 & Word of Mouth (X2) & $\begin{array}{ll}\text { 1. } & \text { Talkers } \\
\text { 2. } & \text { Topics } \\
\text { 3. } & \text { Tools } \\
\text { 4. } & \text { Talking Part } \\
\text { 5. } & \text { Tracking } \\
& \text { (Sernovitz, 2009) } \\
\end{array}$ \\
\hline
\end{tabular}


International Journal of Economics, Business and Accounting Research (IJEBAR)

Peer Reviewed - International Journal

Vol-4, Issue-2, 2020 (IJEBAR)

E-ISSN: 2614-1280 P-ISSN 2622-4771

https://jurnal.stie-aas.ac.id/index.php/IJEBAR

\section{$3 \quad$ Decision makers $(\mathrm{Y})$}

1. Purpose of university choice

2. Information acquirement process to program decision

3. Choice obstinacy

4. Recommending the choice to other people (P. Kotler, 2012)

\section{Research Results}

\subsection{Instrument Test}

The questionnaire results showed that the statement instruments were valid and reliable, fulfilling the regression test requirements as follows.

1. Validity Test

Instrument validity is done to find out if the used statements are reliable and valid as measurements. The validiation test results are as follows.

Tabel 2. Validity test of Reputation

\begin{tabular}{ccccc}
\hline Variable & Statement & $\begin{array}{c}\text { Sig (2- } \\
\text { tailed) }\end{array}$ & $\boldsymbol{\alpha}$ & Justification \\
\hline & $\mathrm{X}_{1.1}$ & 0,010 & 0,05 & Valid \\
\cline { 2 - 5 } & $\mathrm{X}_{1.2}$ & 0,000 & 0,05 & Valid \\
\cline { 2 - 5 } & $\mathrm{X}_{1.3}$ & 0,006 & 0,05 & Valid \\
\cline { 2 - 5 } & $\mathrm{X}_{1.4}$ & 0,000 & 0,05 & Valid \\
\cline { 2 - 5 } & $\mathrm{X}_{1.5}$ & 0,000 & 0,05 & Valid \\
\cline { 2 - 5 } University & $\mathrm{X}_{1.6}$ & 0,012 & 0,05 & Valid \\
\cline { 2 - 5 } (X1) & $\mathrm{X}_{1.7}$ & 0,011 & 0,05 & Valid \\
\cline { 2 - 5 } & $\mathrm{X}_{1.8}$ & 0,000 & 0,05 & Valid \\
\cline { 2 - 5 } & $\mathrm{X}_{1.9}$ & 0,004 & 0,05 & Valid \\
\cline { 2 - 5 } & $\mathrm{X}_{1.10}$ & 0,014 & 0,05 & Valid \\
\cline { 2 - 5 } & $\mathrm{X}_{1.11}$ & 0,000 & 0,05 & Valid \\
\cline { 2 - 5 } & $\mathrm{X}_{1.12}$ & 0,000 & 0,05 & Valid \\
\cline { 2 - 5 } & $\mathrm{X}_{1.13}$ & 0,005 & 0,05 & Valid \\
\cline { 2 - 5 } & $\mathrm{X}_{1.15}$ & 0,013 & 0,05 & Valid \\
\cline { 2 - 4 } & $\mathrm{X}_{1.16}$ & 0,006 & 0,05 & Valid \\
\hline
\end{tabular}

Source: Data analysis results 2019

Tabel 3. Validity test of Word of Mouth

\begin{tabular}{ccccc}
\hline Variable & Statement & Sig (2-tailed) & $\boldsymbol{\alpha}$ & Justification \\
\hline & $X_{2.1}$ & 0,003 & 0,05 & Valid \\
\cline { 2 - 5 } & $X_{2.2}$ & 0,004 & 0,05 & Valid \\
\cline { 2 - 5 } & $X_{2.3}$ & 0,000 & 0,05 & Valid \\
\cline { 2 - 5 } Word of & $X_{2.4}$ & 0,002 & 0,05 & Valid \\
\cline { 2 - 5 } Mouth (X2) & $X_{2.5}$ & 0,013 & 0,05 & Valid \\
\cline { 2 - 5 } & $X_{2.6}$ & 0,004 & 0,05 & Valid \\
\cline { 2 - 5 } & $X_{2.7}$ & 0,001 & 0,05 & Valid \\
\cline { 2 - 5 } & $X_{2.8}$ & 0,000 & 0,05 & Valid \\
\cline { 2 - 5 } & $X_{2.9}$ & 0,002 & 0,05 & Valid \\
\hline & $X_{2.10}$ & 0,000 & 0,05 & Valid \\
\cline { 2 - 5 } & $X_{2.11}$ & 0,003 & 0,05 & Valid \\
\hline
\end{tabular}


International Journal of Economics, Business and Accounting Research (IJEBAR)

Peer Reviewed - International Journal

Vol-4, Issue-2, 2020 (IJEBAR)

E-ISSN: 2614-1280 P-ISSN 2622-4771

https://jurnal.stie-aas.ac.id/index.php/IJEBAR

\begin{tabular}{ccccc}
\hline$X_{2.12}$ & 0,002 & 0,05 & Valid \\
\cline { 2 - 4 } & $X_{2.13}$ & 0,001 & 0,05 & Valid \\
\hline$X_{2.14}$ & 0,000 & 0,05 & Valid \\
\hline$X_{2.15}$ & 0,002 & 0,05 & Valid \\
\hline$X_{2.16}$ & 0,015 & 0,05 & Valid \\
\hline$X_{2.17}$ & 0,036 & 0,05 & Valid \\
\hline$X_{2.18}$ & 0,005 & 0,05 & Valid \\
\hline$X_{2.19}$ & 0,025 & 0,05 & Valid \\
\hline$X_{2.20}$ & 0,005 & 0,05 & Valid \\
\hline
\end{tabular}

Source: Data analysis results 2019

Tabel 4. Validity test of Decision of choice

\begin{tabular}{ccccc}
\hline Variable & Statement & $\begin{array}{c}\text { Sig (2- } \\
\text { tailed) }\end{array}$ & $\boldsymbol{\alpha}$ & Justification \\
\hline $\begin{array}{c}\text { Decision of } \\
\text { choice }\end{array}$ & $Y_{1}$ & 0,000 & 0,05 & Valid \\
\hline$(Y)$ & $Y_{2}$ & 0,000 & 0,05 & Valid \\
\hline & $Y_{3}$ & 0,003 & 0,05 & Valid \\
\hline$Y_{4}$ & 0,001 & 0,05 & Valid \\
\hline$Y_{5}$ & 0,004 & 0,05 & Valid \\
\hline$Y_{6}$ & 0,000 & 0,05 & Valid \\
\hline$Y_{7}$ & 0,002 & 0,05 & Valid \\
\hline$Y_{8}$ & 0,003 & 0,05 & Valid \\
\hline$Y_{9}$ & 0,004 & 0,05 & Valid \\
\hline & $Y_{10}$ & 0,000 & 0,05 & Valid \\
\hline$Y_{11}$ & 0,001 & 0,05 & Valid \\
\hline & $Y_{12}$ & 0,000 & 0,05 & Valid
\end{tabular}

Source: Data analysis results 2019

2. Reliability Test

The reliability coefficient is obtained from the Cronbach's alpha based on standardized items, where if it is bigger than $R$ table $(0,7)$ then the variable is said to be reliable. The analysis results are as follows.

Table 5. Variable Reliability Test

\begin{tabular}{ccc}
\hline $\begin{array}{c}\text { Cronbach's Alpha Based } \\
\text { on Standardized }\end{array}$ & $\boldsymbol{R}$ table & Justification \\
\hline 0,837 & 0,70 & Reliable \\
\hline
\end{tabular}

Table 5 shows that the Cronbach's alpha is larger than $R$ table of 0,7 , thus the data is fit to continue to analysis. 
International Journal of Economics, Business and Accounting Research (IJEBAR)

Peer Reviewed - International Journal

Vol-4, Issue-2, 2020 (IJEBAR)

E-ISSN: 2614-1280 P-ISSN 2622-4771

https://jurnal.stie-aas.ac.id/index.php/IJEBAR

\subsection{Classical Assumption Test}

1. Normality Test

Tabel 6. Normality test

One-Sample Kolmogorov-Smirnov Test

\begin{tabular}{|ll|r|}
\hline & & $\begin{array}{r}\text { Unstandardiz } \\
\text { ed Residual }\end{array}$ \\
\hline N & 50 \\
Normal Parameters & aE-b & Mean \\
Most Extreme Differences & Std. Deviation &, 41064680 \\
& Absolute &, 118 \\
& Positive &, 086 \\
Kolmogorov-Smirnov Z & Negative &,- 118 \\
Asymp. Sig. (2-tailed) &, 833 \\
a. Test distribution is Normal. &, 491 \\
\hline \multicolumn{2}{|c|}{ b. Calculated from data. }
\end{tabular}

Table 6 shows that asymp. Sig. (2-tailed) 0,491 >0,05, thus showing that the residues have a normal distribution.

2. Multicollinearity Test

The multicollinearity test determines if there is a correlation between the independent variables in the regression model. Table 7 shows that each VIF value variable is less than $10(1,006<10)$, with tolerance value greater than $0,1(0,994>1)$, thus confirming no multicollinearity between the variables and thus no correlation between the variables. The results are as follows.

Table 7. Multicollinearity test

\begin{tabular}{lcc}
\hline \multicolumn{1}{c}{ Variabel } & Nilai VIF & Tolerance \\
\hline Reputasi $\left(\mathrm{X}_{1}\right)$ & 1,006 & 0,994 \\
Word of Mouth & 1,006 & 0,994 \\
$\left(\mathrm{X}_{2}\right)$ & & \\
\hline
\end{tabular}

3. Heteroscedasticity Test

Figure 1 showed that the scatterplot of ZPRED and SRESID concentrated above or below the origin value and does not form patterns, therefore fulfilling the heteroscedasticity assumption.

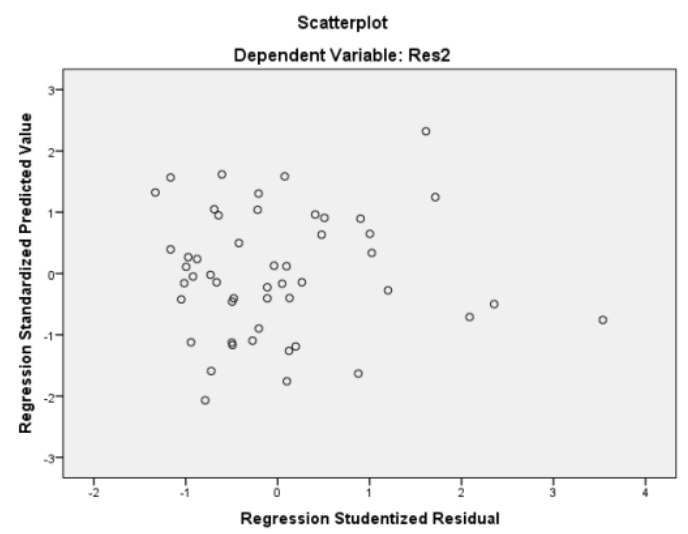

Figure 1. Heteroscedasticity test 
International Journal of Economics, Business and Accounting Research (IJEBAR)

Peer Reviewed - International Journal

Vol-4, Issue-2, 2020 (IJEBAR)

E-ISSN: 2614-1280 P-ISSN 2622-4771

https://jurnal.stie-aas.ac.id/index.php/IJEBAR

4. Autocorrelation test

The autocorrelation test determines if the observation members in the same free variable relates with each other. The test results are shown in Table 8.

Table 8. Durbin-Watson value Model Summary

\begin{tabular}{|l|r|}
\hline Model & $\begin{array}{l}\text { Durbin- } \\
\text { Watson }\end{array}$ \\
\hline 1 & 2,112 \\
\hline
\end{tabular}

a. Predictors (Constant), Word of

Mouth $\left(\mathrm{X}_{2}\right)$, Reputasi $\left(\mathrm{X}_{1}\right)$

b. Dependent Variable : Keputusan

memilih (Y)

Table 8 showed a DW value of 2,12, between the $1,55-2,46$ range, thus proving that no autocorrelation occured in the research data.

\subsection{Data Analysis}

1. Perception Difference Analysis

Table 9 shows the analysis of university reputation perception difference between educational and non-educational students in choosing UNIPA Surabaya as their place of study as follows.

Table 9. Perception difference test

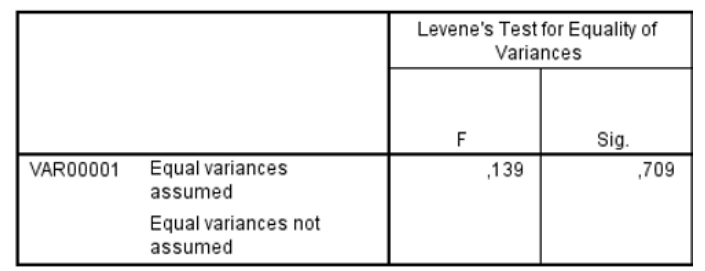

The university reputation perception difference analysis between educational and noneducational students showed a sig value of $0,709(0,709>0,05)$. It shows that educational and non-ecucational students does not have a significant difference in reputation perception in choosing UNIPA Surabaya.

Table 10. Word-of-mouth perception

\begin{tabular}{|c|c|c|c|}
\hline & \multicolumn{2}{|c|}{$\begin{array}{l}\text { Levene's Test for Equality of } \\
\text { Variances }\end{array}$} \\
\hline & & $\mathrm{F}$ & Sig. \\
\hline VAR00001 & $\begin{array}{l}\text { Equal variances } \\
\text { assumed } \\
\text { Equal variances not } \\
\text { assumed }\end{array}$ & 6,736 & .010 \\
\hline
\end{tabular}

The perception difference analysis test for word of mouth between educational and noneducational students showed a sifg value of $0,010(0,010<0,5)$. It means that theres is a significant difference in word of mouth perception between educational and non-educational students in choosing UNIPA Surabaya.

2. Determining Analysis 
International Journal of Economics, Business and Accounting Research (IJEBAR)

Peer Reviewed - International Journal

Vol-4, Issue-2, 2020 (IJEBAR)

E-ISSN: 2614-1280 P-ISSN 2622-4771

https://jurnal.stie-aas.ac.id/index.php/IJEBAR

Table 11 shows the determining analysis between educational and non-educational students in choosing UNIPA Surabaya as their place of study as follows.

Table 11. Determining analysis

Model Summary

\begin{tabular}{|l|c|c|c|c|}
\hline Model & $\mathrm{R}$ & $\mathrm{R}$ Square & $\begin{array}{c}\text { Adjusted R } \\
\text { Square }\end{array}$ & $\begin{array}{c}\text { Std. Error of } \\
\text { the Estimate }\end{array}$ \\
\hline 1 &, $249^{\mathrm{a}}$ &, 062 &, 048 &, 36940 \\
\hline
\end{tabular}

The university reputation and word-of-mouth variables in educational and non-educational students give a $4,8 \%$ influence when deciding to choose UNIPA Surabaya as their place of study.

3. Multiple Linear Regression Analysis

Table 12 shows the multiple linear regression analysis to educational and non-educational students in choosing UNIPA Surabaya as their place of study.

Tabel 12. Multiple linear regression analysis

Coefficients $^{\mathrm{a}}$

\begin{tabular}{|cc|r|r|r|}
\hline \multirow{2}{*}{ Model } & \multicolumn{3}{|c|}{ Unstandardized Coefficients } & $\begin{array}{c}\text { Standardized } \\
\text { Coefficients }\end{array}$ \\
\cline { 3 - 5 } & \multicolumn{2}{|c|}{ B } & Std. Error & \multicolumn{1}{c|}{ Beta } \\
\hline 1 & (Constant) & 1,813 &, 649 & \\
& Reputasi &, 317 &, 123 &, 223 \\
& WOM &, 166 &, 092 &, 157 \\
\hline
\end{tabular}

a. Dependent Variable: Keputusan

From Table 12 we may derive a multiple linear equation as follows.

$$
Y=1,813+0,317 X_{1}+0,166 X_{2}
$$

The constant 1,813 means that if the university reputation and word-of-mouth variables are zeroed then the decision variable in choosing UNIPA Surabaya is 1,813 . The reputation variable coefficient of 0,317 means that reputation variable is directly proportional to the decision variable in choosing UNIPA Surabaya. If the reputation value increases by 1 , then the decision value will rise by 0,317 , and vice versa. The word-of-muth coefficient of 0,166 means that the WOM variable is directly proportional to the decision variable in choosing UNIPA Surabaya. If the WOM value increases by 1 , then decision variable will increase by 0,166 , and vice versa. From the regression analysis we found out that there are significant differences between educational and non-educational students in choosing UNIPA Surabaya as their place of study, shown from the reputation and word-of-mouth perspectives.

\section{Discussion}

The results of the study show that the decision of students to study at PGRI Adi Buana University in Surabaya is seen from the perception of the university's reputation, both students of educational and non-educational programs are no different. The reputation factor is one of the factors considered important for students in choosing tertiary institutions. Higher education that has a good reputation, must have good quality in producing output. This research supports (Harahap, Hurriyati, Gaffar, Wibowo, \& Amanah, 2017) where the university's reputation has a positive and significant influence on students' decisions to study. (Saif, Nipa, \& Siddique, 2016) the results of his research stated that choosing the right university for study is a crucial issue, where the reputation of universities as the most important thing is considered in choosing universities for higher education. The findings (Echchabi \& Al-Hajri, 2018) in his research stated that reputation is a major factor in choosing universities.

Test results differ between the WOM perceptions of students of educational study programs and non-educational study programs have a sig value of $0.010(0.010<0.05)$. This means that the perception of WOM from students of educational study programs and non-educational study 


\section{International Journal of Economics, Business and Accounting Research (IJEBAR) \\ Peer Reviewed - International Journal \\ Vol-4, Issue-2, 2020 (IJEBAR) \\ E-ISSN: 2614-1280 P-ISSN 2622-4771}

https://jurnal.stie-aas.ac.id/index.php/IJEBAR

programs is different in terms of choosing PGRI Adi Buana University Surabaya as a place of study. Compared with educational study programs, non-education study program students consider factors to obtain deeper and more specific information related to the attributes offered, it is possible that students of educational study programs are more motivated by their interest in the chosen field of study. This condition is in line with (Ming, 2010) that characteristics in tertiary institutions involve broad matters such as student interests.

\section{Conclusion}

From our research to determine the difference in perception of university reputation and word-ofmouth to choose UNIPA Surabaya as their place of study between educational and non-educational students of academic year 2018-2019, we may conclude as follows : Reputation perception of educational and non-educational students has a sig value of $0,709(0,709>0,05)$. This shows that both educational and non-educational students are in sync when considering reputation as the basis of deciding to choose UNIPA Surabaya. The word-of-mouth perception difference between educational and non-educational students has a sig value of $0,010(0,010<0,05)$. This shows that there are significant differences between educational and non-educational students in valuing word-of-mouth to decide on choosing UNIPA Surabaya.

\section{References}

Agrey, L., \& Lampadan, N. (2014). Determinant Factors Contributing to Student Choice in Selecting a University. Journal of Education and Human Development, 3(2), 391-404. Retrieved from http://jehdnet.com/journals/jehd/Vol_3_No_2_June_2014/22.pdf

Aula, H. M., \& Tienari, J. (2011). Becoming "world-class"? Reputation-building in a university merger. Critical Perspectives on International Business. https://doi.org/10.1108/17422041111103813

Arikunto S. (2010), Prosedur Penelitian , suatu pendekatan praktek, Edisi Revisi, Cetakan ke 14 , Jakarta, Rineka Cipta

Assosiation American Marketing. (n.d.). Definitions of Marketing. Retrieved from www.ama.org website: https://www.ama.org/the-definition-of-marketing-what-is-marketing/

Echchabi, A., \& Al-Hajri, S. (2018). FACTORS INFLUENCING STUDENTS' SELECTION OF UNIVERSITIES: THE CASE OF OMAN. Journal of Education Research and Evaluation. https://doi.org/10.23887/jere.v2i2.13694

Eka, hafilah. (2015). Pengaruh Word Of Mouth (Wom) Dan Citra Merek Terhadap Keputusan Mahasiswa Memilih Program Strata 1 (S-1) DI Universitas Islam Negeri Maulana Malik Ibrahim Malang. Acta Universitatis Agriculturae et Silviculturae Mendelianae Brunensis. https://doi.org/10.1377/hlthaff.2013.0625

Fauzan, A. (2016). Jumlah Perguruan Tinggi di Indonesia Kalahkan Eropa, Tapi.... Retrieved from http://kabarkampus.com/ website: http://kabarkampus.com/2016/01/jumlah-perguruan-tinggi-diindonesia-kalahkan-eropa-tapi/

Gunarto, M., \& Gaffar, V. (2016). Analisis Persepsi Dan Preferensi Masyarakat Terhadap Reputasi Pemeringkat Perguruan Tinggi. Journal Ilmu Manajemen, 5(2), 129-142. Retrieved from http://eprints.binadarma.ac.id/3245/1/417-830-1-SM.pdf

Hagel, P., \& Shaw, R. (2007). The Influence of Delivery Mode on Consumer Choice of University. Association for Consumer Research, 8, 531-536.

Harahap, D. A., Hurriyati, R., Gaffar, V., Wibowo, L. A., \& Amanah, D. (2017). Effect of Word of Mouth on Students Decision to Choose Studies in College. 793-797. https://doi.org/10.5220/0007090007930797

Hasan, A. (2010). Marketing. Yogyakarta: MedPress.

Huete-Alcocer, N. (2017). A literature review of word of mouth and electronic word of mouth: Implications for consumer behavior. Frontiers in Physiology, 8(JUL), 1-4.

International Journal of Economics, Business and Accounting Research (IJEBAR) Page 249 
International Journal of Economics, Business and Accounting Research (IJEBAR)

Peer Reviewed - International Journal

Vol-4, Issue-2, 2020 (IJEBAR)

E-ISSN: 2614-1280 P-ISSN 2622-4771

https://jurnal.stie-aas.ac.id/index.php/IJEBAR

https://doi.org/10.3389/fpsyg.2017.01256

Kotler, P., \& Keller, K. L. (2016). Marketing Management. Global Edition (Vol. 15E). In Pearson Pretice Hall. https://doi.org/10.1080/08911760903022556

Kotler, P. (2012). Kotler P. Marketing management/Philip Kotler, Kevin Lane Keller. Pearson Educ Int. 2012. Pearson Education International.

Kotler, P. \& K. L. K. (2009). Manajemen pemasaran jilid 1, edisi Ketiga belas, Terjemahan Bob Sabran. Jakarta: Erlangga. https://doi.org/10.1177/0022022111434597

Mahendra Fakhri, Alini Gilang, N. R. (2017). Analisis Faktor Pembentuk Keputusan Pemilihan Perguruan Tinggi Swasta Universitas Telkom (Studi Pada Mahasiswa Prodi S1 Administrasi Bisnis Fakultas Komunikasi Dan Bisnis Universitas Telkom Angkatan 2016). Jurnal Ekonomi, Bisnis \& Entrepreneurship, 11(1). $\quad$ Retrieved from http://jurnal.stiepas.ac.id/index.php/jebe/article/view/166

Mazzarol, T., Soutar, G., \& Limnios, E. M. (2012). Member Loyalty in Co-operative Enterprises: A Preliminary Assessment. 26th Annual ANZAM Conference, (December), 5-7.

Medan, U. (2018). Strategi Branding Perguruan Tinggi Untuk Menarik Minat Mahasiswa Baru.

Mehboob, F., Shah, S. M. M., \& Bhutto, N. A. (2012). Factors Influencing Students Enrollment Decisions in Selection of Higher Education Institutions. Interdisciplinary Journal of Contemporary Research In Business, 4(5). Retrieved from https://journalarchieves23.webs.com/558-568.pdf

Ming, J. S. K. (2010). Institutional Factors Influencing Students' College Choice Decision in Malaysia: A Conceptual Framework. International Journal of Business and Social Science, 1(3), 53-58. Retrieved from http://www.ijbssnet.com/journals/Vol._1_No._3_December_2010/6.pdf

Özdemir, A., Tozlu, E., Şen, E., \& Ateşoğlu, H. (2016). Analyses of Word-of-mouth Communication and its Effect on Students' University Preferences. Procedia - Social and Behavioral Sciences. https://doi.org/10.1016/j.sbspro.2016.11.022

Pemerintah RI. (2005). Undang-undang Republik Indonesia Nomor 14 Tahun 2005 tentang Guru dan Dosen. Produk Hukum.

Prasetyo, B. E. (2018). Hubungan Antara Persepsi Terhadap Word Of Mouth (Wom) Dengan Intensi Membeli Melalui Media Internet (Online Shopping) Pada Mahasiswa Fakultas Psikologi Universitas Islam Negeri Sunan Ampel Surabaya (Universitas Islam Negeri Sunan Ampel). Retrieved from http://digilib.uinsby.ac.id/26811/2/Budi Eko Prasetyo_J01214006.pdf

Rudhumbu, N., Tirumalai, A., \& Kumari, B. (2017). Factors that Influence Undergraduate Students' Choice of a University: A Case of Botho University in Botswana. International Journal of Learning and Development, 7(2), 27. https://doi.org/10.5296/ijld.v7i2.10577

Sernovitz, A. (2009). Word of Mouth Marketing: How Smart Companies Get People Talking. New York: Kaplan Publishing.

Sudaryono. (2014). Perilaku Konsumen Dalam Perspektif Pemasaran. Jakarta: Lentera Ilmu Cendekia.

Sumarwan, U. (2011). Perilaku Konsumen: Teori dan Penerapannya Dalam Pemasaran. Bogor: Ghalia Indonesia \& MMA-IPB.

Suta, I. P. G. A. (2006). Kinerja Pasar Perusahaan Publik Di Indonesia: Suatu Analilis Reputasi Perusahaan (XVI). Jakarta: Yayasan Sad Satria Bhakti.

Sonjaya, W. (2014). Manajemen Pemasaran Perguruan Tinggi. Retrieved from kompasiana.com website: https://www.kompasiana.com/wawansonjaya/54f6785fa3331191178b4b37/manajemenpemasaran-perguruan-tinggi

Wibowo, A. J. I. (2014). Kinerja Riset Universitas, Reputasi Universitas, Dan Pilihan Universitas: Sebuah Telaah Sistematis. Jurnal Manajemen Maranatha, 13(2). Retrieved from https://media.neliti.com/media/publications/113755-ID-kinerja-riset-universitas-reputasi-unive.pdf

Wulandini, P., \& Saputra, R. (2017). Pengambilan Keputusan Mahasiswa dalam Memilih Perguruan Tinggi Swasta di Pekanbaru. JSSH (Jurnal Sains Sosial Dan Humaniora), 1(2), 93 - 102.

International Journal of Economics, Business and Accounting Research (IJEBAR) Page 250 
International Journal of Economics, Business and Accounting Research (IJEBAR)

Peer Reviewed - International Journal

Vol-4, Issue-2, 2020 (IJEBAR)

E-ISSN: 2614-1280 P-ISSN 2622-4771

https://jurnal.stie-aas.ac.id/index.php/IJEBAR

https://doi.org/10.30595/jssh.v1i2.1788 